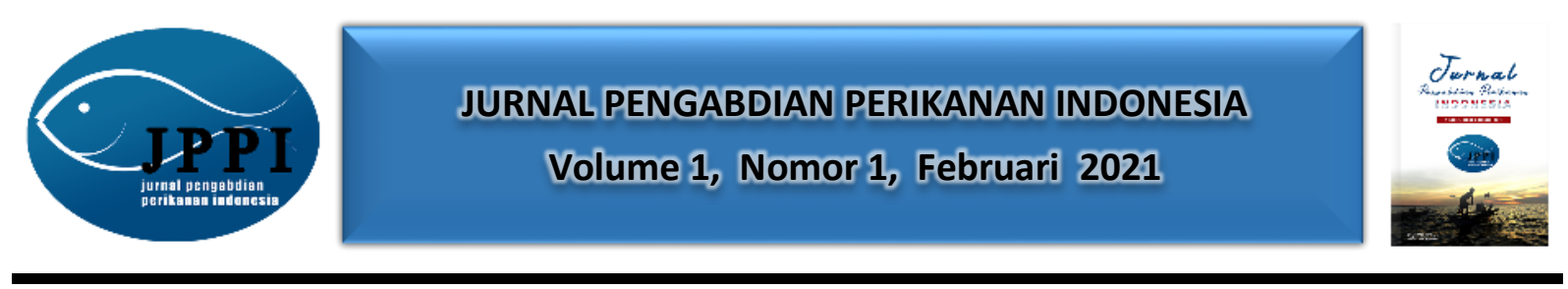

\title{
PENGELOLAAN SAMPAH PLASTIK MENJADI EKOBRIK UNTUK MENEKAN LAJU PENCEMARAN SAMPAH MIKROPLASTIK YANG MENGANCAM KELANGSUNGAN HIDUP BIOTA PERAIRAN TELUK BUMBANG, KABUPATEN LOMBOK TENGAH
}

\author{
Ibadur Rahman, Chandrika Eka Larasati, Saptono Waspodo, Soraya Gigentika, Edwin Jefri
}

Program Studi Ilmu Kelautan Universitas Mataram

Jalan Pendidikan Nomor 37 Kota Mataram

Alamat korespondensi : ibadur.rahman@unram.ac.id

(Tanggal Submission: 3 Desember 2020, Tanggal Accepted : 2 Februari 2021)

\section{Keyword: Abstrak :}

sampah Sampah plastik merupakan permasalahan serius karena sifatnya yang sangat sulit plastik, biota terurai secara alami. Berbagai penelitian menunjukkan terdapat sejumlah konsentrasi perairan, plastik dalam tubuh organisme perairan, seperti: plankton, kekerangan, krustasea, ekobrik dan ikan. Kandungan plastik pada hewan tersebut dapat dipindahkan ke hewan pemangsanya termasuk manusia dalam rantai makanan. Konsentrasi plastik pada tubuh manusia dapat memicu pertumbuhan sel kanker yang mengancam kesehatan dan kelangsungan hidup manusia. Pengabdian kepada masyarakat ini bertujuan untuk menambah kesadaran masyarakat mengenai ancaman sampah mikroplastik terhadap lingkungan dan biota perairan, serta mengenai solusi pengelolaan sampah plastik. Kegiatan pengabdian kepada masyarakat ini menggunakan beberapa pendekatan, yaitu: (1) survei tentang pemahaman dan perilaku masyarakat terhadap sampah plastik; (2) penyuluhan mengenai ancaman sampah plastik; (3) pelatihan pembuatan ekobrik untuk mengurangi laju produksi sampah plastik. Kegiatan pengabdian kepada masyarakat ini dihadiri kelompok nelayan Teluk Bumbang dan Kelompok Sadar Wisata (Pokdarwis) Desa Mertak, Kecamatan Pujut, Kabupaten Lombok Tengah. Hasil survei menunjukkan bahwa sebagaian besar masyarakat masih membuang sampah di sembarang tempat sedangkan yang lainnya membuang sampah ke TPS (Tempat Pembuangan Sementara). Setelah mendapatkan penyuluhan mengenai ancaman sampah plastik, masyarakat menunjukkan komitmennya untuk berhenti membuang sampah sembarangan dan berkomiten dalam upaya mengelola sampah plastik menjadi produk yang bernilai ekonomis, misalnya ekobrik.

Panduan Sitasi (APPA $7^{\text {th }}$ edition) :

Rahman, I., Larasati, C.E., Waspodo, S., Gigentika, S., \& Jefri, E. (2021). Pengelolaan Sampah Plastik Menjadi Ekobrik Untuk Menekan Laju Pencemaran Sampah Mikroplastik Yang Mengancam Kelangsungan Hidup Biota Perairan Teluk Bumbang, Kabupaten Lombok Tengah. Jurnal Pengabdian Perikanan Indonesia, 1 (1), 62-68. http://doi.org/ 10.29303/jppi.v1i1.82 


\section{PENDAHULUAN}

Sampah plastik merupakan permasalahan serius yang terjadi di seluruh negara di dunia dewasa ini, karena sifatnya yang sangat sulit untuk terurai secara alami. Diperkirakan terdapat 322 juta ton plastik yang diproduksi setiap tahun, dan telah ada lebih dari 5 miliar ton potongan plastik yang tersebar di lingkungan, dimana 250 ribu ton diantaranya mengambang di permukaan laut (Jamieson et al., 2019). Ezeoha \& Ezenwanne (2019) menyebutkan bahwa diperlukan waktu hingga ratusan tahun untuk dapat menguraikan beberapa gram sampah plastik.

Bentuk derifat dari sampah plastik ini yaitu sampah mikroplastik yang berukuran kurang dari $5 \mathrm{~mm}$ (Sharma \& Chatterjee, 2017). Mikroplastik berasal dari polutan plastik yang hancur menjadi partikel-partikel kecil dan tersebar di lingkungan sekitar. Mikroplastik merupakan ancaraman serius, khususnya bagi biota-biota perairan. Beberapa penelitian menunjukkan bahwa mikroplastik telah ditemukan pada organ pencernaan sejumlah biota, seperti: plankton, kekerangan, krustasea, echinodermata, ikan, dan cetasean (Jamieson et al., 2019).

Banyaknya mikroplastik yang ditemukan di laut, membuat makanan laut menjadi sumber mikroplastik yang paling umum dalam makanan, terutama jenis kekerangan karena hewan ini bersifat filter feeder, yaitu mengumpulkan makanan dengan menyaring air laut. Naji et al. (2018) menyebutkan bahwa telah ditemukan 0,2-21,0 partikel mikroplastik pada setiap gram jaringan tubuh kekerangan. Mikroplastik yang termakan oleh biota laut tersebut tentunya akan mengganggu kelangsungan hidupnya, disebabkan nutrisi yang seharusnya diserap oleh usus terhalang oleh plastik (Jamieson et al., 2019).

Naji et al. (2018) dalam penelitiannya mengungkapkan bahwa konsentrasi mikroplastik yang lebih tinggi ditemukan pada biota pemangsa disebabkan adanya transfer energi dalam peristiwa rantai makanan, dikenal dengan istilah bioakumulasi. Manusia, yang juga merupakan pemakan biota laut juga berpeluang mendapatkan limpahan kandungan mikroplastik yang berasal dari hewan laut yang dimakannya. Sharma \& Chatterjee (2017) menambahkan bahwa mikroplastik yang masuk dalam sel dan jaringan manusia dapat menyebabkan perubahan struktur kromoson yang memicu gangguan kesuburan, obesitas dan kanker.

Masyarakat Teluk Bumbang sejatinya telah memahami akan dampak negatif yang ditimbulkan oleh sampah, terutama sampah plastik, yaitu: mengganggu keindahan panorama alam, sampah plastik seringkali tersangkut pada baling-baling kapal nelayan atau tersangkut pada jaring ikan dan area budidaya biota perikanan masyarakat. Namun, karena minimnya pengetahuan masyarakat tentang alternatif pengelolaan sampah menyebabkan selama ini sampah hanya berakhir di tempat pembakaran (dibakar), ditimbun di dalam tanah, dibuang ke TPS (Tempat Pembuangan Sementara), di buang ke sungai atau ke laut. Praktek pengelolaan sampah seperti ini tentunya tidak menyelesaikan masalah sampah, namun akan menimbulkan masalah lainnya seperti pencemaran udara, mengganggu resapan air tanah, bahkan sampah yang dibuang ke sungai atau laut akan menjadi ancaman bagi kelangsungan biota perairan.

Kegiatan pengabdian kepada masayarakat ini berupaya untuk memberikan gambaran kepada masyarakat mengenai potensi ancaman yang ditimbulkan sampah plastik terhadap lingkungan perairan dan kelangsungan hidup biota yang hidup di dalamnya, bahkan berpotensi mengancam kesehatan dan keselamatan manusia. Dengan mengetahui bahaya sampah plastik, masyarakat diharapakan merubah kebiasaan buruk membuang sampah sembarangan dan lebih peduli terhadap kebersihan dan pelestarian lingkungan dari sampah.

Kegiatan pengabdian ini juga berupaya memberikan alternatif bentuk pengelolaan sampah plastik menjadi produk bernilai ekonomi, yaitu ekobrik. Ekobrik adalah botol plastik berbahan dasar polyethylene terephthalate (PET) yang diisikan sampah-sampah anorganik hingga padat dan keras seperti batu bata. Meskipun ekobrik tidak menyelesaikan masalah sampah plastik hingga tuntas, namun cara tersebut cukup efektif untuk mengurangi laju pencemaran sampah plastik di perairan karena sampah-sampah tersebut dimanfaatkan oleh manusia menjadi bentuk-bentuk kerajinan tangan, misalnya kursi, meja, atau sebagai bahan bangunan pengganti batu bata. Dengan demikian, 
produk ekobrik selain berperan dalam menjaga pelestarian lingkungan hidup namun juga berdampak pada peningkatan taraf hidup masyarakat melalui kerajinan tangan yang diperjualbelikan.

\section{METODE KEGIATAN}

\section{Waktu dan Tempat}

Kegiatan pengabdian kepada masyarakat ini dilakukan pada bulan Agustus sampai November 2020 di kawasan Teluk Bumbang, Desa Mertak, Kecamatan Pujut, Kabupaten Lombok Barat, meliputi kegiatan penyuluhan, dan pelatihan pembuatan produk kerajinan berbahan dasar sampah plastik, yaitu berupa ekobrik.

\section{Tahapan kegiatan}

Kegiatan pengabdian kepada masyarakat ini dibagi menjadi beberapa tahapan :

1) Survei lokasi dan perizinan

Survei lokasi meliputi kegiatan peninjauan ke lokasi pengabdian, menggali informasi tentang permasalahan yang dihadapi masayarakat menggunakan metode wawancara langsung dengan masyarakat, dan studi literatur terhadap kegiatan penelitian atau pengabdian yang pernah dilakukan sebelumnya di Teluk Bumbang, Kabupaten Lombok Tengah. Sedangkan perizinan meliputi kegiatan surat-menyurat, pendataan calon peserta pengabdian, serta permohonan izin kepada pihak berwenang untuk menyelenggarakan kegiatan pengabdian kepada masyarakat.

2) Survei kuesioner mengenai persepsi dan perilaku masyarakat terhadap sampah plastik.

Survei kuesioner dilakukan untuk mengukur tingkat pemahaman masyarakat terhadap bahaya dan ancaman sampah plastik, serta mengetahui perilaku masyarakat dalam mengelola sampah plastik.

3) Penyuluhan mengenai ancaman sampah plastik

Kegiatan penyuluhan meliputi penyampaian materi mengenai ancaman sampah plastik di lingkungan perairan, sehingga masyarakat mendapatkan wawasan yang luas yang diharapkan dapat menggugah kesadaran masyarakat untuk menjaga kebersihan lingkungan dari polusi sampah plastik.

4) Pelatihan pembuatan ekobrik

Pelatihan pembuatan kerajinan tangan yaitu dengan menghadirkan pakar pembuat kerajinan tangan yang akan melatih masyarakat Teluk Bumbang untuk membuat produk olahan berbahan dasar sampah plastik yaitu ekobrik.

5) Evaluasi

Kegiatan evaluasi diperlukan untuk mengetahui seberapa efektif kegiatan pengabdian yang telah dilakukan, dan seberapa besar dampak yang diberikan dalam meningkatkan kesadaran masyarakat mengenai bahaya sampah bagi dirinya dan lingkungan, serta menambah wawasan masyarakat bahwa sampah plastik juga memiliki nilai ekonomis yang dapat meningkatkan pendapatan dan kesejahteraan masyarakat.

\section{HASIL DAN PEMBAHASAN}

Hasil survei kuesioner terhadap masyarakat Teluk Bumbang, Desa Mertak, Kecamatan Pujut, Kabupaten Lombok Tengah menunjukkan bahwa pemahaman masyarakat mengenai bahaya sampah plastik terhadap kelangsungan hidup makhluk hidup, khususnya organisme perairan masih tergolong rendah. Selama ini masyarakat cenderung menganggap sampah plastik hanya sebatas mengganggu estetika pemandangan alam, menimbulkan bau tak sedap dan menjadi sarang kuman penyakit. Namun, bahwa sampah plastik dapat masuk ke dalam perairan sehingga secara tidak sengaja dikonsumsi oleh organisme perairan kemudian berpindah ke organisme lainnya yang lebih tinggi dalam tingkatannya dalam rantai makanan, belum dipahami oleh sebagaian besar masyarakat. 
Pemahaman masyarakat bahwa sampah plastik dapat digunakan kembali (reuse), dikurangi (reduce), dan didaur ulang (recycle) masih tergolong rendah. Masyarakat cenderung memiliki pemahaman bahawa sampah plastik adalah produk akhir yang tidak memiliki manfaat lagi sehingga harus dibuang. Padahal sejatinya sampah plastik dapat dikelola dengan lebih bijak, sehingga mendatangkan manfaat dan bernilai ekonomis.

Pemahaman masyarakat mengenai ancaman sampah plastik yang masih tergolong rendah dapat disebabkan beberapa alasan, yaitu: tingkat pendidikan masyarakat yang cenderung rendah dan terbatasnya akses informasi. Berdasarkan hasil survei terhadap 13 orang responden, sebanyak 10 orang ( $77 \%$ ) belum pernah mengenyam pendidikan SMA, bahkan terdapat salah seorang peserta yang buta aksara. Di samping itu, akses informasi yang terbatas juga menjadi kendala. Sebagian besar masyarakat masih menemui kesulitan dalam mengakses informasi tentang pengelolaan sampah plastik, karena terbatasnya fasilitas baik jaringan internet, ketiadaan perangkat elektronik (gadget), dan minimnya kegiatan penyuluhan dari aparatur desa atau yang lainnya.

Kegiatan pengabdian kepada masyarakat ini berupaya untuk menjadi salah satu akses masyarakat, sehingga masyarakat bertambah wawasan dan kesadarannya dalam menjaga kelestarian lingkungan dari masalah sampah, khususnya sampah plastik. Adapun media yang digunakan dalam sosialisasi / penyuluhan yaitu berupa brosur.
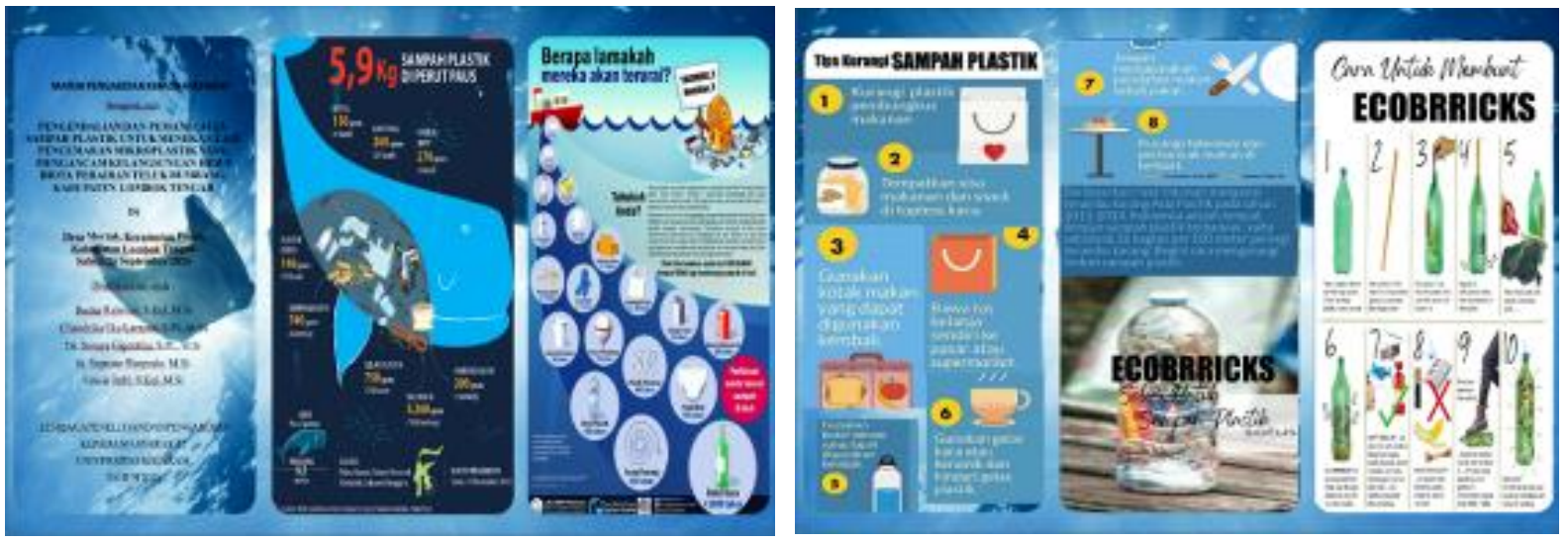

Gambar 1. Desain brosur dalam sosialisasi pengelolaan sampah plastik (kiri: tampak depan, kanan: tampak belakang)

Pemilihan brosur sebagai media sosialisasi dikarenakan lokasi kegiatan pengabdian berada di tepian pantai kawasan Teluk Bumbang, sehingga cukup sulit untuk disediakan fasilitas elektronik seperti proyektor LCD. Di samping itu, media brosur memiliki keunggulan karena mudah dibawa dan dapat disebarluaskan kepada khalayak, dan tidak terbatas pada sejumlah orang yang menjadi peserta kegiatan penyuluhan, sehingga informasi yang diberikan lebih masif. 


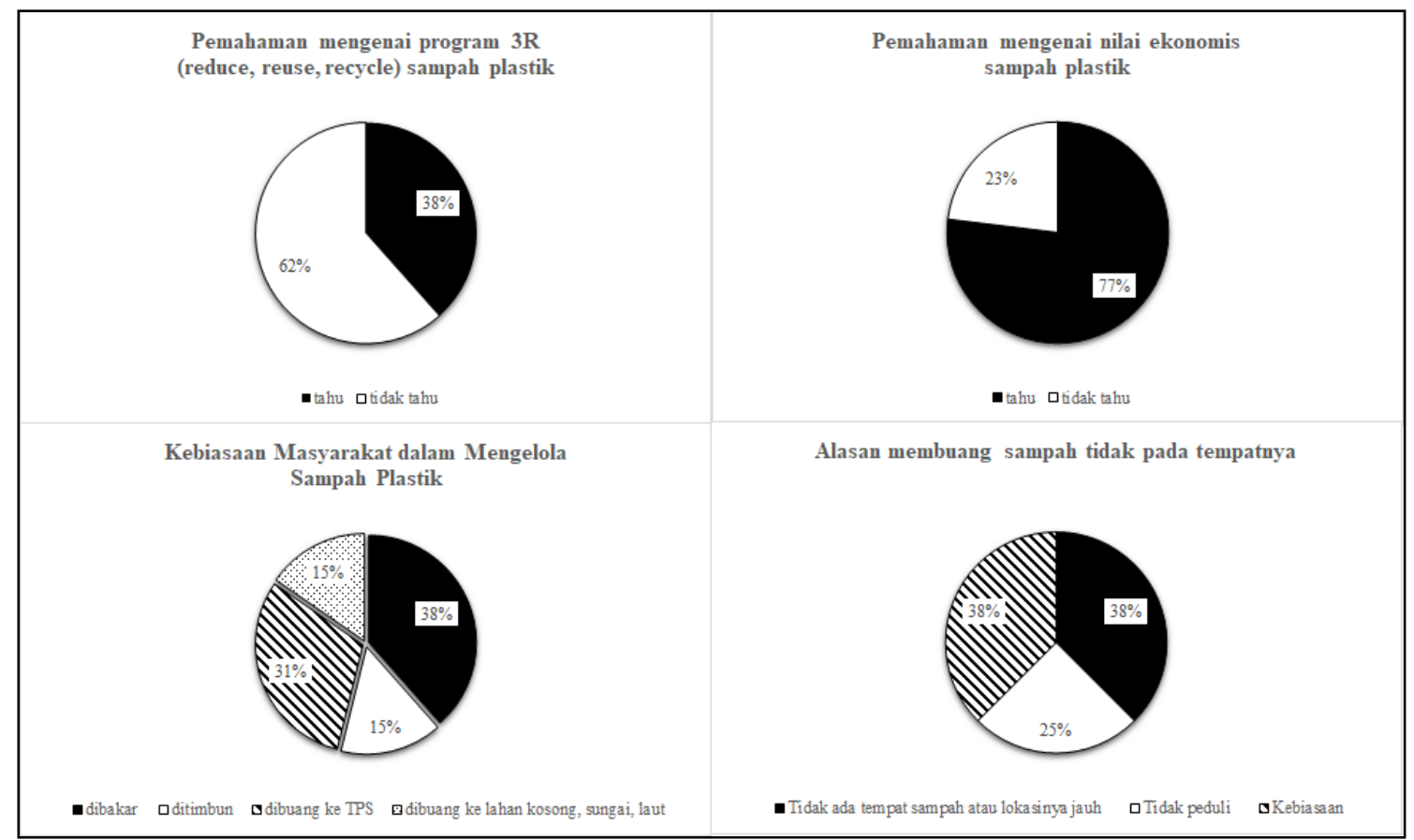

Gambar 2. Hasil survei kuesioner mengenai pemahaman dan kebiasaan masyarakat dalam mengelola sampah plastik

Masyarakat Teluk Bumbang memiliki kebiasaan yang berbeda-beda dalam mengelola sampah plastik, yaitu dengan cara dibakar (38\%); ditimbun dalam tanah (15\%); dibuang ke TPS (Tempat Pembuangan Sementara, 32\%); sedangkan sebagian yang lain (15\%) membuang sampah di sembarang tempat, seperti di lahan kosong, di sungai atau di laut. Adapun alasan yang mendasari masyarakat membuang sampah secara sembarangan yaitu karena fasilitas pembuangan sampah sulit dijangkau (38\%), karena tidak peduli / acuh (24\%), sedangkan 38\% lainnya beralasan karena hal tersebut sudah sudah menjadi kebiasaan yang membudaya.

Menyelesaikan masalah sampah plastik di kawasan Teluk Bumbang merupakan perkara yang tidak mudah. Hal ini dikarenakan sebagian besar masyarakat masih kurang peduli terkait persoalan sampah dan masih menganggap bahwa sampah belum mencapai kondisi yang dapat mengancam kelangsungan hidup mereka. Bagaimanapun juga, masyarakat harus selalu dipahamkan bahwa sampah, khususnya sampah plastik, merupakan ancaman serius yang harus segera diantisipasi. Di antara dampak buruk sampah plastik yaitu:

1. Merusak keindahan panorama / pemandangan alam. Hal ini tentunya merugikan tidak hanya bagi wisatawan yang ingin menikmati panorama keindahan alam, namun juga merugikan masyarakat yang mengambil keuntungan dari sektor pariwisata, seperti penjual makananminuman, penjaja souvenir, dan sebagainya.

2. Menimbulkan bau tak sedap karena bercampur dengan sampah organik. Sampah yang tidak diolah dengan baik dapat membusuk dan menimbulkan bau tak sedap. Selanjutnya sampah tersebut menjadi sarang kuman penyakit yang dapat mengancam kesehatan dan keselamatan masyarakat yang berada di sekitarnya.

3. Sampah plastik seringkali tersangkut di baling-baling kapal nelayan, di area tambak/ budidaya sehingga mengganggu aktivitas dan produktivitas tambak.

4. Sampah plastik yang masuk ke dalam perairan akan mengakibatkan pencemaran perairan yang dapat mengancam kelangungan hidup berbagai organisme perairan, seperti: penyu, ikan, kekerangan, lumba-lumba, paus, bahkan pada akhirnya dapat membahayakan manusia karena manusia berada pada level puncak dalam rantai makanan. Hal ini dikarenakan konsentrasi plastik yang dicerna oleh organisme pada level bawah dapat dipindahkan kepada organisme dengan level di atasnya, dikenal dengan istilah bioakumulasi. 
Mengingat besarnya ancaman sampah plastik terhadap kelangsungan hidup makhluk hidup dan lingkungan, maka diperlukan upaya untuk mengendalikan laju produksi sampah plastik. Adapun upaya-upaya yang dapat dilakukan, di antaranya:

1. Mengurangi penggunaan barang-barang berbahan dasar plastik, seperti: kantong kresek, air kemasan gelas/botol plastik.

2. Beralih dari penggunaan barang-barang berbahan plastik sekali pakai menjadi barang-barang yang dapat dipakai berulang kali berbahan dasar kertas, serat kayu, bambu, dan sebagainya.

3. Mendaur ulang sampah plastik menjadi bijih plastik atau bentuk lainnya sehingga dapat diolah kembali menjadi produk plastik yang bermutu dan bernilai jual.

4. Membuat ekobrik.

Ekobrik merupakan salah satu bentuk pengolahan sampah plastik dengan cara yang unik dan cukup efektif untuk mengendalikan banyaknya sampah plastik yang dibuang secara sembarangan. Adapun cara pembuatan ekobrik adalah sebagai berikut:

1. Sebuah botol plastik bekas disediakan sebagai wadah pembuatan ekobrik, berikut tongkat yang digunakan untuk memampatkan sampah plastik yang diisikan ke dalam botol plastik.

2. Sampah plastik yang telah dibersihkan menggunakan detergen (untuk membunuh kuman/bakteri penyakit) dan telah dikeringkan kemudian dicacah-cacah sehingga mudah dimasukkan ke dalam botol plastik dan agar dapat memuat lebih banyak sampah plastik.

3. Potongan sampah plastik yang telah dimasukkan dimampatkan menggunakan tongkat sepadat mungkin, sehingga produk ekobrik semakin padat dan keras dan menampung sampah plastik dengan maksimal.

Hal yang perlu diperhatikan dalam pembuatan ekobrik adalah menghindari masuknya zat-zat yang dapat membusuk, cairan atau zat kimia karena dapat membahayakan keselamatan.

Ekobrik sejatinya belum mampu menyelesaikan masalah sampah plastik secara tuntas. Hal ini dikarenakan sampah plastik yang terdapat di lingkungan tidak dimusnahkan hingga tidak meninggalkan bekas/ampas, namun sampah-sampah plastik tersebut hanya dikumpulkan dan dimampatkan dalam satu wadah botol plastik. Meskipun tidak menyelesaikan sampah plastik secara paripurna, ekobrik merupakan bentuk alternatif yang cukup efektif dalam mengendalikan permasalahan sampah plastik yang jumlahnya semakin banyak setiap harinya.

\section{KESIMPULAN DAN SARAN}

\section{Kesimpulan}

1. Tingkat pemahaman dan kesadaran masyrakat Teluk Bumbang terhadap ancaman sampah plastik terhadap lingkungan dan kelangsungan hidup makhluk hidup masih tergolong rendah.

2. Pengendalian masalah sampah plastik di kawasan Teluk Bumbang terkendala kebiasaan masyarakat membuang sampah sembarangan, rendahnya tingkat kepedulian masyarakat, dan fasilitas tempat pembuangan sampah yang cenderung sulit dijangkau.

3. Ekobrik merupakan salah satu bentuk alternatif pengendalian sampah plastik yang cukup efektif dan ramah lingkungan seiring semakin bertambahnya jumlah produksi sampah plastik setiap harinya.

Saran

Ekobrik merupakan bentuk alternatif pengendalian sampah plastik yang cukup efektif, namun belum mampu menyelesaikan masalah sampah plastik hingga tuntas. Bentuk pengolahan sampah plastik menjadi bijih plastik akan lebih efektif dan memberikan manfaat yang lebih banyak, baik terhadap kelestarian lingkungan maupun dalam meningkatkan kesejahteraan hidup masyarakat. 


\section{UCAPAN TERIMA KASIH}

Ucapan terimakasih sedalam-dalamnya penulis sampaikan kepada Universitas Mataram yang telah membiayai sepenuhnya kegiatan pengabdian kepada masyarakat ini melalui skema DIPA PNBP Universitas Mataram No.: 2179/ UN18/LPPM/2020. Ucapan terimakasih juga disampaikan kepada Perangkat Desa Mertak, Kecamatan Pujut, Kabupaten Lombok Tengah yang telah menfasilitasi pertemuan Tim Pengabdian dengan masyarakat, juga kepada Kelompok Nelayan Teluk Bumbang dan Kelompok Masyarakat Sadar Wisata (POKDARWIS) Desa Mertak yang telah berpartisipasi dalam kegiatan kepada masyarakat ini. Tak lupa penulis ucapkan terimakasih kepada mahasiswa Program Studi IImu Kelautan Universitas Mataram a.n Adam Romara Gulit Rizki yang banyak membantu dalam kegiatan pengabdian ini.

\section{DAFTAR PUSTAKA}

Ezeoha SL \& Ezenwanne JN. Production of Biodegradable Plastic Packaging Film from Cassava Starch. IOSR Journal of Engineering (IOSRJEN), Vol. 3 (10): 14-20.

Jamieson AJ, Brooks LSR, Reid WDK, Piertney SB, Narayanaswamy BE, and Linley TD. 2019. Microplastics and synthetic particles ingested by deep-sea amphipods in six of the deepest marine ecosystems on Earth. R. Soc. open sci. 6: 180667.

Naji A, Nuri M, Vethaak AD. 2018. Microplastics contamination in molluscs from the northern part of the Persian Gulf. Environmental Pollution , Vol 235: 113-120.

Sharma S \& Chatterjee S. 2017. Microplastic pollution, a threat to marine ecosystem and human health: a short review. Environmental Science and Pollution Research, Vol 24: 21530-21547.

Surono BU. 2005. Berbagai Metode Konversi Sampah Plastik Menjadi Bahan Bakar Minyak, Jurnal Teknik, Vol 3 No.1/April 2013, $32-40$. 